pages of small print, is somewhat voluminous as such. It might be of some service to men preparing for an examination, provided they have an intimate knowledge of standard works, so as to discard errors and evade false impressions. Apart from such use, we cannot recommend the book as a suitable one for students, although the author shows evidence in the text of considerable acquaintance with recent literature, and the work is more up to date than many of its class.

Hernia : its Cause and Treatment. By R. W. Murray, F.R.C.S. Pp. vi., 99. London: J. \& A. Churchill. I908.In this small work the author advocates the "saccular theory" of causation of hernia as originally emphasised by Mr. Hamilton Russell. With this view, the desirability of getting rid of the sac is of the utmost importance, and operative methods are preferred in almost every case. The more complicated operations are rejected, and the procedure favoured is much the same as that advocated by the late Sir William Banks. There is not much that is new in the book, which has been mainly written to support the views to which reference has been made, and this results in a tendency to treat most cases in a stereotyped plan of operation, to the practical exclusion of treatment by means of trusses.

\title{
BOOK ON ANATOMY.
}

Anatomical Terminology. By Lewellys F. Barker, M.D. Pp. ix., I03. London: J. \& A. Churchill. I907.-The desirability of a uniform nomenclature in scientific matters is so obvious, that it should need no arguments to emphasise it. In the department of anatomy this ought now to be secured by the adoption of the terminology accepted at Basle by the German Anatomical Society. Its advantages are overwhelming. The terms are in Latin, thus rendering them intelligible all the world over, and synonyms are eliminated. A concession to terms associated with individuals is made by adding, in certain instances, the name in brackets. The Latin portion of the work under notice is the outcome of a Commission appointed by the Society in I889, which consisted of Professors von Kölliker, O. Hertwig, His, Kollmann, Merkel, Schwalbe, Toldt, Waldeyer, and v. Bardeleben, with Professor W. Krause as editor-in-chief. The English equivalents have been prepared by Dr. Barker, with the help of Dr. Benson A. Cohoe, both members of the staff of Johns Hopkins Hospital. Ultra-conservatives will probably be able to offer many objections to the proposals. These seem to have been anticipated by the Commission, whose conclusions, and the reasons for them, are admirably set forth in an extremely lucid introduction which Dr. Barker has written for this volume. This introduction is full of interest, and well worth consideration 
even by those who are not anatomical specialists. Dr. Barker states that the new edition of Morris's Anatomy adopts the nomenclature. In course of time it ought to meet with universal acceptance.

Les venins des Animaux Venimeuse et la Sérothérapie Antivenimeuse. By A. Calmette. Paris: Masson. I907.-In this volume Calmette has gathered together his publications and observations of the last fifteen years. It forms an admirable record of patient work. Those interested in the subject will find it of the utmost value for reference. After detailing the morphology of the snakes of Europe, Asia, Africa, Australia and America, the author discusses the physiological actions of the several venoms, and the value of vaccination and anti-toxin treatment. The poisons of certain fishes, batrachians, saurians, and mammals are then considered. We must express our appreciation of the numerous illustrations. These alone make the book worth its money.

The Bacteriological Examination of Disinfectants. By William Partridge, F.I.C. Pp. 66. London: The Sanitary Publishing Co. I907.-This brochure, which is introduced by a preface by Major C. E. P. Fowler, will be welcomed by those who have to deal with matters of practical sanitation. The difficult problems met with in determining the values of the various disinfectants are fully discussed, and the technique of the methods given in detail. There is a special chapter on the influence of organic matter on disinfectants.

The Reduction of Cancer. By the Hon. Rollo Russelz. Pp. 62. London: Longmans, Green \& Co. I907.-This strange little sermon appearing in scientific guise, although pleasantly enough written and insisting on a sound mode of living, has little or no real claim to its title or to a place in scientific literature. The burden of its teaching may be gathered perhaps from a single sentence: "All ingesta not really nutritious, and containing a strong poison which pleasantly excites, are as a matter of fact, when habitually and largely consumed, not only luxuries, but destructive luxuries." From this text, by a careful compilation of statistical extracts, almost any proposition might be bolstered up, and the remainder of the book goes to show that " in a long list of countries all the small consumers of flesh, tea, coffee, beer and tobacco have a small cancer rate; all the large consumers have a high rate." But the author's arguments are very loosely strung together. Many authorities are laid under contribution, general non-committal statements are strained into direct proofs ; dictetic precautions in cases of aneurysm are represented as " having a bearing on liability to cancer " which " is not remote," until the brain reels under the battery of eminent names, sensational figures, and hasty generalisation into a sort of submissive 